JURNAL KETAHANAN NASIONAL

Vol. 24, No.1, April 2018, Hal 77-93

DOI:http://dx.doi.org/ 10.22146/jkn.32923

ISSN:0853-9340(Print), ISSN:2527-9688(Online)

Online sejak 28 Desember 2015 di :http://jurnal.ugm.ac.id/JKN

VOLUME 24

No. 1, April 2018

Halaman 77-93

\title{
Nasib Petani Dan Ketahanan Pangan Wilayah (Studi Tentang Kebijakan Pemerintah Dan Respons Masyarakat Desa Mulyodadi, Bantul Ketika Harga Komoditas Pertanian Naik)
}

\author{
Pajar Hatma Indra Jaya \\ Prodi Pengembangan Masyarakat, Universitas Islam Negeri Sunan Kalijaga Yogyakarta \\ Email: 198104282003121003@uin-suka.ac.id
}

\begin{abstract}
The background of this research was the continuously increasing phenomenon of the land use and job conversions from agricultural to nonagricultural sector. The data showed the reduce of people enthusiasm for being a farmer. Hence, it could threat the regional food resilience. This research aimed to observed the government policys when the prices of agricultural commodity increased and how the farmers response.

To answered the objective of this research, the researcher looked at phenomenon of increasing price of chilli at the beginning of 2017 and the increasing price of rice in the beginning of 2018. Meanwhile, the response of the farmers was sought by making an interview with 33 farmers living in Mulyodadi Village, Bantul Regency.

This research found that though the government had a vision to improved the prosperity of the farmer, it seemed that the government tended to reduced the price of agricultural commodity as soon as possible. As a result, it triggered the perception among farmers that the policy on the price of agricultural commodity in Indonesia did not give any hope to obtained the economic prosperity. They also viewed that their life would not be better as long asa the work in agricultural sector. As a consequence, the enthusiasm to be a farmer continously declined and weakened the regional/national food resilience.
\end{abstract}

Keywords: Policy, Work Conversion, Prosperity of Farmer, Regional Food Resilience

\begin{abstract}
ABSTRAK
Penelitian ini dilatarbelakangi oleh fenomena alih fungsi lahan dan konversi pekerjaan dari pertanian ke non-pertanian yang setiap tahun angkanya selalu meningkat. Data tersebut menunjukan gairah masyarakat untuk bertani semakin hari semakin kecil sehingga dapat membahayakan ketahanan pangan wilayah. Berdasarkan latar belakang tersebut penelitian ini bertujuan untuk melihat kebijakan apa yang diambil pemerintah ketika harga-harga komoditas pertanian naik, serta bagaimana respons petani terhadap kebijakan tersebut.

Untuk menjawab tujuan penelitian itu, peneliti melakukan kajian terhadap kebijakan yang diambil pemerintah ketika terjadi kenaikan harga cabai pada awal tahun 2017 dan kenaikan beras pada awal 2018. Sedangkan respons petani dicari dengan melakukan wawancara terhadap petani yang tinggal di Desa Mulyodadi Kabupaten Bantul.

Penelitian ini menemukan bahwa meskipun pemerintah mempunyai visi berusaha untuk meningkatkan kesejahteraan petani, namun berdasarkan kebijakan-kebijakan yang diambil ketika harga komoditas pertanian naik menunjukkan bahwa pemerintah cenderung tidak suka dan berusaha menurunkan harga komoditas pertanian secara cepat. Akibatnya muncul pengetahuan di kalangan petani bahwa kebijakan harga komoditas pertanian di Indonesia tidak memberi mereka harapan untuk mendapatkan kesejahteraan ekonomi. Muncul pengetahuan bahwa nasib mereka tidak akan baik ketika tetap bekerja di sektor pertanian. Akibatnya gairan bertani terus menerus mengalami penurunan yang dapat melemahkan ketahanan pangan wilayah.
\end{abstract}

Kata Kunci: Kebijakan, Konversi Pekerjaan, Kesejahteraan Petani, Ketahanan Pangan Wilayah 


\section{PENGANTAR}

Menurut Rostow untuk memperoleh kemakmuran, pembangunan suatu negara harus diarahkan dengan cara melakukan perubahan dari masyarakat tradisional menuju masyarakat modern. Pembangunan dicirikan dengan pergeseran orientasi masyarakat dari basis ekonomi pertanian menuju industri/take off (Solivetti, 2005: 721). Di sisi yang lain muncul Teori Pembagian Kerja Internasional. Menurut teori ini pembangunan sebuah negara harus memperhatikan potensi alam atau anugerah Tuhan yang diberikan kepada sebuah negara. Setiap negara harus melakukan spesialisasi produksi sesuai dengan keunggulan komparatif yang dimiliki. Negara-negara di belahan bumi katulistiwa dengan karakter tanah yang subur dan curah hujan yang baik menjadi modal penting untuk pembangunan dan pencapaian kesejahteran masyarakat. Sedangkan negaranegara di belahan utara yang iklimnya tidak cocok untuk pertanian sebaiknya mengembangkan sektor industri (Budiman, 2000: 16).

Pembangunan di negara dengan karakteristik tanah yang subur harus menjadikan pertanian sebagai modalnya. Hal ini penting karena tidak setiap daerah dianugerahi tanah yang subur. Indonesia termasuk negara tropis dengan sinar matahari yang cukup dan tanah yang subur sehingga potensial menjadi daerah pertanian yang baik. Selain itu jika suatu negara mengabaikan pembangunan di bidang pertanian, terutama persoalan pangan akan memunculkan persoalan baru, yaitu penurunan produktivitas pertanian yang mempengaruhi ketersediaan pangan wilayah.

Alam dan kesuburan bumi Indonesia merupakan modal pembangunan yang harus dirawat dan dikelola untuk memenuhi kebutuhan pangan seluruh masyarakat. Hal ini telah muncul dalam tekad (visi)
Kementerian Pertanian, yaitu mewujudkan kedaulatan pangan dan kesejahteraan petani (Kementerian Pertanian, 2015: 108). Namun jika melihat hasil pembangunan selama ini, angka kemiskinan di perdesaan selalu lebih tinggi daripada di perkotaan. Bahkan BPS menyimpulkan profil orang miskin sering melekat pada orang-orang yang bekerja di sektor pertanian. BPS menyimpulkan bahwa hanya $29,77 \%$ kepala rumah tangga tidak miskin yang bekerja di sektor pertanian (Badan Pusat Statistik, 2016: 52-53). Muncul indikasi bahwa bekerja di sektor pertanian tidak akan pernah membuat kehidupan masyarakat menjadi sejahtera. Akibatnya gairah bertani menjadi berkurang.

Selama tahun 2003 sampai tahun 2013 terjadi penurunan jumlah rumah tangga yang bekerja di sektor pertanian sebanyak 5,096 juta rumah tangga. Dilihat dari usia, rata-rata pekerja yang berada di sektor pertanian usianya telah di atas 50 tahun (Kementerian Pertanian, 2015: 77, 92). Secara mikro, laju konversi pekerjaan ini juga dibuktikan dengan penelitiannya Putra (2015) yang menyimpulkan terjadinya penurunan rumah tangga petani dengan laju 1.07 persen setiap tahunnya di Kota Batu (Putra, 2015: 76). Di Bantul juga terjadi penurunan rumah tangga pertanian, dari 154.288 pada tahun 2003 menjadi 127.894 pada tahun 2013 atau turun sebanyak 17,11\%. Di Kabupaten Sleman juga terjadi penurunan sebesar 34.296\% (Badan Pusat Statistik Provinsi Daerah Istimewa Yogyakarta, 2013: 6).

Hilangnya pesona untuk bekerja di sektor pertanian diikuti dengan peningkatan konversi lahan pertanian ke non-pertanian. Setiap tahun angkanya selalu meningkat, pada tahun 2015 terjadi konversi lahan pertanian ke-non pertanian seluas 24.200 hektar. Hal ini sama artinya Indonesia kehilangan lahan pertanian 
lebih dari 2.000 hektar setiap bulannya atau 66 hektar setiap hari atau 2,7 hektar setiap jam (Kementerian Pertanian, 2016: 8). Data lain, menunjukkan bahwa angka konversi lahan pertanian di Indonesia mencapai 96.512 ha setiap tahun atau sebanding dengan luas dua kabupaten di Daerah Istimewa Yogyakarta (Mulyani, Kuncoro, Nursyamsi, dan Agus, 2016: 121). DI Yogyakarta sendiri setiap tahun kehilangan sekitar 234 hektar lahan pertaniannya (Asni, 2016: 32). Data ini juga terjadi hampir di semua kota di Indonesia (Wibowo, 2015: 110). Data-data tersebut menunjukan bahwa sektor pertanian telah kehilangan pesonanya.

Ada berbagai cara yang dapat dilakukan pemerintah untuk mengatasi meningkatnya laju konversi lahan pertanian. Salah satunya dengan membuat kebijakan berupa peraturan pemerintah tentang pelarangan konversi lahan. Namun kebijakan tersebut tidak menyelesaikan persoalan hilangnya gairah masyarakat untuk bertani. Akibatnya ketika petani sudah tidak punya gairan bertani, namun pemerintah melarang konversi lahan akan timbul dampak berupa banyaknya lahan yang dibiarkan menganggur tidak diolah. Dengan demikian gairah bertani merupakan roh ketahanan pangan wilayah. Gairah bertani ini punya kaitan dengan kesejahteraan petani.

Dalam Rational Choice Theory berlaku konsep Economic Man, orang akan cenderung berusaha untuk memaksimalkan keuntungan dan menghindari kerugian (Chattopadhyay dan Ghosh, 1995: 169). Konversi pekerjaan ke non pertanian akan terus menerus terjadi ketika pekerjaan sebagai petani tidak melahirkan harapan kesejateraan. Salah satu harapan petani untuk bermimpi memperoleh kesejahteraan ekonomi adalah ketika harga komoditas pertanian sedang meningkat. Namun saat ini, dalam praktiknya pemerintah seakanakan mengeluarkan kebijakan-kebijakan yang kontradiksi dengan harapan petani tersebut. Untuk itu penelitian ini berusaha memeriksa kebijakan-kebijakan apa saja yang diambil pemerintah ketika terjadi kenaikan harga komoditas pertanian? Bagaimana respons petani terkait kebijakan yang diambil pemerintah tersebut?

Untuk menjawab rumusan masalah di atas peneliti memeriksa dua kasus kenaikan harga komoditas pertanian, yaitu kenaikan harga cabai pada awal tahun 2017 dan kenaikan harga beras pada akhir tahun 2017 sampai awal tahun 2018. Pengumpulan data pada awalnya dilakukan dengan memeriksa kebijakan yang dikeluarkan oleh pemerintah dalam merespons dua kasus kenaikan harga komoditas pertanian tersebut. Setelah itu peneliti melakukan wawancara dengan para petani untuk mendapatkan respons mereka atas kebijakan yang telah diambil pemerintah. Pengambilan data dilakukan pada bulan Januari 2018 kepada petani yang tergabung di Kelompok Tani dan Ternak Andhini Lestari Desa Mulyodadi yang berjumlah 33 orang. Kelompok tani tersebut dipilih sebagai informan karena pertimbangan kemudahan akses untuk mendapatkan data, serta mewadahi petani dengan tingkat ekonomi dan jumlah kepemilikan lahan yang bervariasi. Pada awalnya peneliti menyebarkan pertanyaan tertutup (skala Likert) dalam pertemuan kelompok. Beberapa pertanyaan yang membutuhkan ulasan lebih dalam peneliti tindak lanjuti dengan wawancara lanjutan.

\section{PEMBAHASAN}

\section{Kenaikan Harga Pertanian dan Kebijakan Impor}

Undang-Undang Nomor 18 Tahun 2012 tentang Pangan, menyebutkan bahwa pangan 
merupakan kebutuhan dasar manusia yang paling utama dan pemenuhannya merupakan bagian dari hak asasi manusia yang dijamin di dalam Undang-Undang Dasar (UUD) Negara Republik Indonesia. Pangan yang utama dari bangsa Indonesia adalah beras. Dalam acara peletakan batu pertama pembangunan Institut Pertanian Bogor, Soekarno menyampaikan pidato dengan judul Soal Hidup atau Mati. Dalam pidato yang dibukukan tersebut, beliau menyampaikan bahwa hidup atau matinya sebuah bangsa terkait dengan kemampuan bangsa tersebut untuk menjaga persediaan makanan bagi rakyatnya (Soekarno, 1952: 1, 7; Suryana, Rachman, dan Hartono, 2014: 155-156).

Indonesia sebenarnya merupakan negara yang kuat karena mempunyai sumber daya alam yang melimpah, termasuk tanah yang subur yang menghasilkan beras. Produktivitas beras di Indonesia juga bisa dikatakan baik. Mengikuti data Kementerian Pertanian, hasil gabah di Indonesa pada tahun 2016 sebanyak 79,1 juta ton, meningkat $11,7 \%$ dibanding dengan tahun 2014 yang berjumlah 70.8 juta ton (Kementerian Pertanian RI, 2016, 101; Kementerian Pertanian, 21 Februari 2017; 7, 21). Meskipun terjadi konversi lahan pertanian yang cukup masif, namun pengintensifan usaha pertanian mampu meningkatkan produktivitas beras (Karini, 2013: 13). Namun demikian melihat harga beras nasional setiap tahun, data menunjukan bahwa harga beras selalu mengalami fluktuasi, meskipun harga tertinggi tidak sampai naik di atas Rp 3.000,00.

Pada akhir tahun 2017 harga beras mengalami kenaikan. Beras kualitas sedang (medium) yang harga acuannya Rp 9.450,00 (Berdasar Peraturan Menteri Perdagangan Republik Indonesia Nomor 27/M-DAG/ PER/5/2017) pada pertengahan bulan Januari telah mengalami kenaikan menjadi Rp 12.000,00 (di beberapa kota). Sebenarnya harga ini tidak jauh berbeda dengan harga beras rata-rata di Indonesia pada tahun 2016 yang menurut BPS sebesar Rp 11.511,00 (Badan Pusat Statistik, 17 Januari 2018). Meskipun demikian banyak orang meributkan kenaikan harga beras ini.

Kenaikan harga beras tahun 2017 membuat pemerintah mengeluarkan kebijakan impor beras. Jika melihat Nawacita sebagai agenda prioritas pemerintahan Jokowi-JK maka pemerintah sendiri sebenarnya punya tekad untuk tidak melakukan impor beras. Meskipun demikian, jika melihat data impor beras Indonesia pada tahun 2017, pemerintah tidak benar-benar menghentikan impor beras. Tahun 2017 pemerintah mengimpor beras kualitas premium sebanyak 256.559.605 kg atau senilai US\$ 119.780.099 (Badan Pusat Statistik, 2018: 68).

Ketika menghadapi kenaikan beras pada awal tahun 2018, pemerintah juga secara cepat mengambil langkah menyetujui impor beras kualitas sedang sebanyak 500.000 ton. Aturan impor beras tersebut dibuat baru, yaitu tertuang dalam Peraturan Menteri Perdagangan No 1 Tahun 2018 tentang Ketentuan Ekspor dan Impor Beras tanggal 3 Januari 2018. Menurut pemerintah kebijakan impor beras tidak akan mengganggu kesejahteraan petani (Pramadiba, 12 Januari 2018). Namun demikian, menggunakan skala Likert, penelitian ini mengukur sikap atau respons petani terhadap kebijakan impor beras. Hasil penelitian menyimpulkan bahwa kebijakan impor beras direspons secara bulat oleh semua informan penelitian ini (petani) dengan menjawab sangat tidak setuju dengan kebijakan impor beras. Jono salah satu petani menyampaikan: 
"Kami sesungguhnya sangat tidak setuju dengan kebijakan impor beras, tapi bagaimana lagi suara kita tidak didengar pemerintah. Harga beras bulan-bulan ini naik kan karena hama wereng yang membuat produksi padi petani berkurang dan petani rugi. Jika pemerintah impor beras untuk mengatasinya maka kami mengalami rugi kwadrat" (Jono, 13 Januari 2018)

Hampir semua penelitian tentang kebijakan impor beras juga memaparkan dampak negatifnya di masa yang akan datang. Penelitian Siringo dan Daulay (2014) menyimpulkan bahwa impor beras berkorelasi negatif dengan produktivitas beras nasional, peningkatan kuota impor beras berpengaruh secara signifikan terhadap penurunan produktivitas pertanian dalam kurun waktu 1986-2012 (Siringo dan Daulay, 2014). Kebijakan impor beras mempengaruhi turunnya harga beras dan berpengaruh secara nyata terhadap menurunnya nilai tukar petani (Rahim, 2010: 29-36).

Kebijakan pemerintah yang selalu melakukan impor beras ketika harga naik ini membuat petani memberi kesimpulan bahwa harga beras tidak akan pernah mengalami kenaikan yang signifikan, bahkan cenderung rendah meskipun hasil panen padi di Indonesia mengalami penurunan (paceklik). Hal ini seperti yang terjadi pada tahun 2017 , ketika hasil produksi padi turun akibat hama wereng dan tahun 1997 ketika terjadi fenomena badai El-Nino. Dua fenomena tersebut seharusnya memicu kenaikan harga beras karena hama wereng membuat hasil panen petani menurun dan ketika panen menurun seharusnya harga naik sehingga muncul keseimbangan harga yang membuat petani tidak merugi (hukum ekonomi). Namun kenyataannya ketika harga naik, pemerintah secara cepat membuka kran impor beras sehingga petani tidak merasakan harga baik ini dalam waktu yang lama. Dengan tidak adanya harga kejutan yang baik tersebut semakin membuat keyakinan bahwa petani tidak akan pernah menikmati hasil dari kenaikan harga. Bahkan memunculkan pengetahuan, dilihat dari kesejahteraan ekonomi, petani identik dengan kemiskinan.

Menurut data rata-rata harga beras kualitas medium (IR II) perbulan di Yogyakarta, harga beras perkilogramnya mencapai $\mathrm{Rp}$ 10.500,00 baru terjadi pada bulan Desember 2017. Pada bulan Oktober dan November harga beras medium masih berada di angka Rp 10.050,00, sedangkan di bulan-bulan sebelumnya berada di bawah Rp 10.000,00. Meskipun harga beras baru mencapai Rp 10.500,00, namun pada bulan Februari 2018 beras impor telah masuk ke Indonesia. Secara rinci fluktuasi harga beras di DI Yogyakarta terlihat dalam gambar 1 s.d 3 di bawah ini.

Selain beras, pada tahun 2017 harga cabai juga mengalami kenaikan yang signifikan. Harga cabai rawit merah setiap kilogramnya sempat menyentuh harga lebih dari Rp 120.000,00 dan harga cabai merah keriting sempat di harga Rp 60.000,00. Sebenarnya fluktuasi harga ini hampir terjadi setiap awal tahun, seperti pada tahun 2014 dan juga 2015. Namun, setiap ada kenaikan, termasuk pada periode kenaikan awal tahun 2017 pemerintah mengeluarkan kebijakan impor cabai.

Berdasarkan Data BPS, impor cabai dari bulan Januari 2017 sampai April 2017 sebanyak 98,8 ton dengan nilai US\$ 155,6 ribu. Harga cabai akhirnya menjadi murah. Pada tahun 2017 mahalnya harga cabai hanya bertahan selama tiga bulan. Pada bulan April 2017 harga cabai sudah turun menjadi Rp 18.050,00, bahkan pada bulan September cabai bisa dikatakan tidak laku karena di tingkatan petani harganya hanya 
Gambar 1

Fluktuasi Harga Beras Kualitas Medium (IR II)

Selama Tahun 2017 Di Yogyakarta

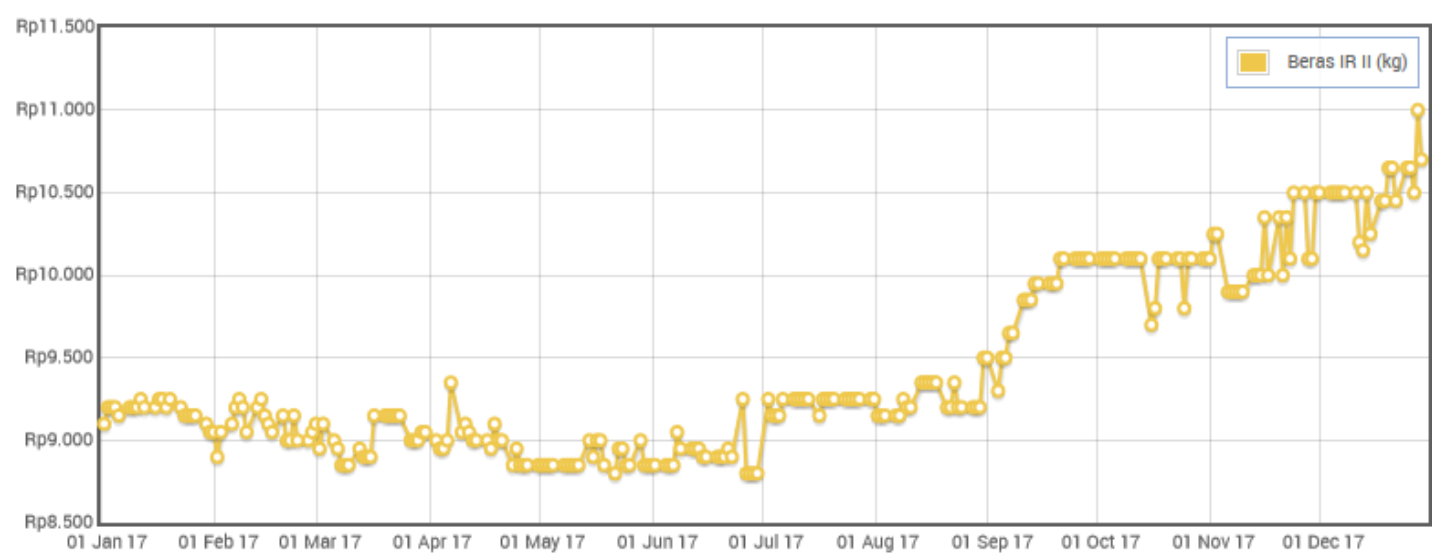

Sumber : Data Tim Pengendali Inflasi Daerah DIY Tahun 2018 (http://tpid-diy.org/statistik/laporantabel)

Gambar 2

Fluktuasi Harga Beras Di DIY Akhir Tahun 2017 Dan Awal 2018

(Harga Dalam Rp/Kg)

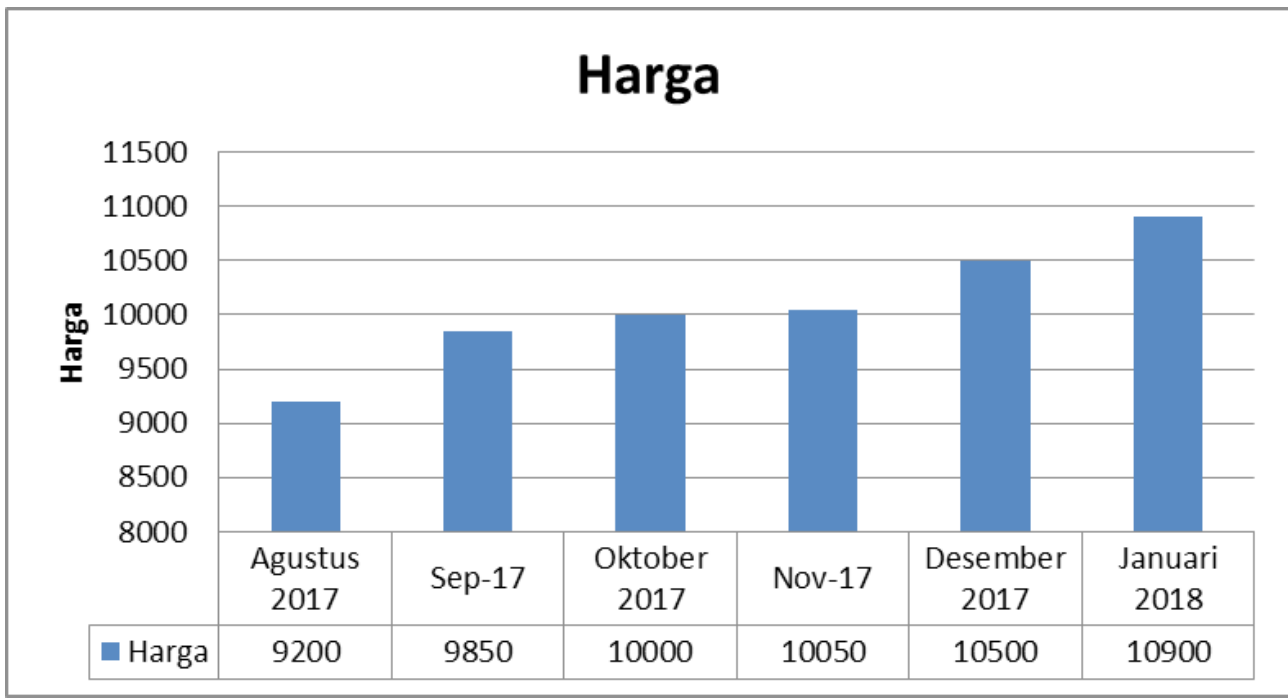

Sumber : Diolah dari data Tim Pengendali Inflasi Daerah DIY (http://tpid-diy.org/statistik/ laporan-tabel)

Rp 5.000,00 per kilogram. Akibatnya petani di Seloharjo Bantul membiarkan cabainya tidak panen dan membagi-bagikannya secara gratis (Tribun Yogyakarta, 15 September 2017). Situasi-situasi ini semakin menguatkan pendapat bahwa menjadi petani itu menderita. Ketika harga turun pemerintah juga tidak membeli cabai mereka dengan harga baik atau mengirimnya ke luar negeri.

Suara-suara petani yang mengeluh ketika harga komoditas jatuh ini seperti tidak didengar dan ditanggapi oleh para pembuat kebijakan. Dalam konsep teori postkolonial mereka adalah kelompok sub-altern, Narayan (2000) menyebut 
Gambar 3

Fluktuasi Harga Cabai Merah Keriting Tahun 2016-2017

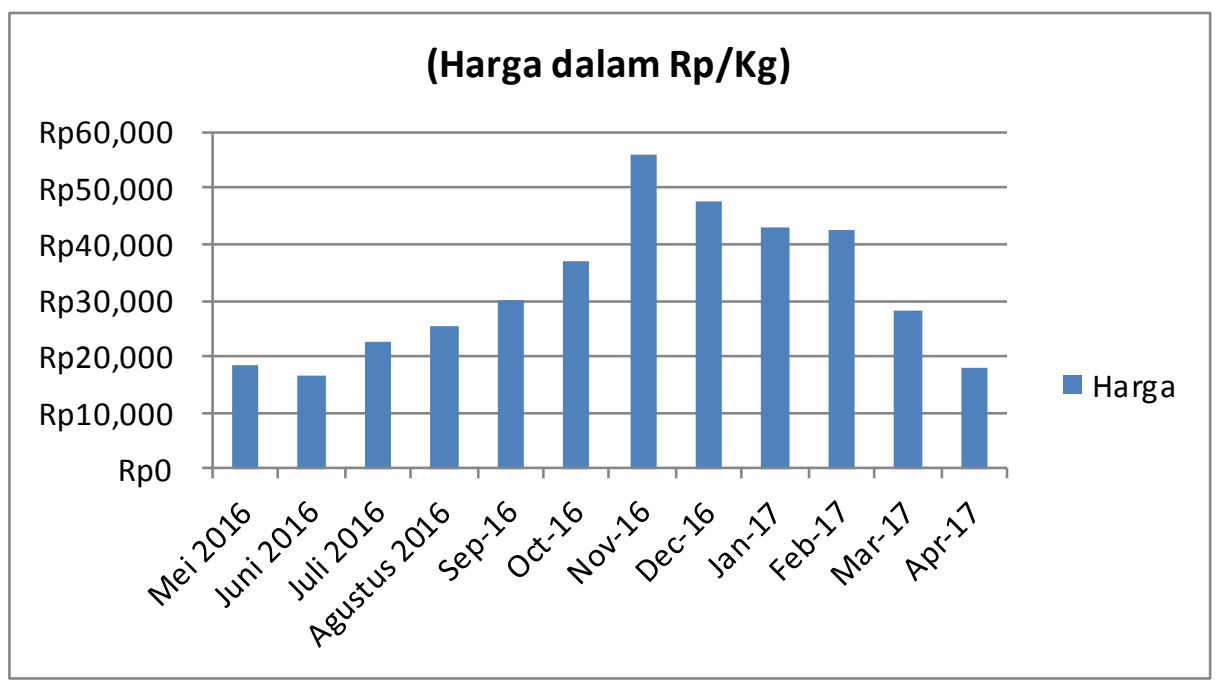

Sumber : Diolah dari data Tim Pengendali Inflasi Daerah DIY Tahun 2017 (http://tpiddiy.org/statistik/laporan-tabel)

mereka sebagai kelompok-kelompok bisu yang suaranya tidak pernah didengar oleh pembuat kebijakan. Padahal jika dilihat dari jumlahnya, petani di Indonesia angkanya cukup banyak. Dengan demikian ketika harga komoditas pertanian jatuh, hal itu sebenarnya dirasakan oleh banyak orang. Namun demikian para petani ini tidak mempunyai akses untuk menyuarakan aspirasinya.

Ketika pemerintah tidak mendengarkan suara petani menurut Scott (1985:317) dalam buku Weapons of The Weak, mungkin saja petani melakukan perlawanan. Scott menyebut perlawanan petani sebagai resistensi, yaitu perlawanan yang tidak terorganisir dan terangterangan hidden transcript. Itulah perlawanan orang kalah. Menggunakan terminologi petani rasional dari Samuel Popkin, tindakan yang ditempuh oleh petani merupakan tindakan yang paling rasional, tindakan yang mempertimbangkan untung rugi (Popkin, 1976: 259). Petani sebagai kelompok orang kalah ini kemudian kehilangan semangatnya untuk bertani, minimal mereka secara sadar kemudian tidak menjadikan petani sebagai pekerjaan yang harus diwariskan kepada anakanaknya. Akibatnya terjadi konversi pekerjaan antar generasi. Bahkan dalam penelitian ini ada juga petani yang membiarkan lahannya tidak digarap. Daripada gagal karena hama wereng atau berhasil namun harganya dimurahkan pemerintah maka lebih baik mereka tidak bercocok tanam. Luka-luka akibat kebijakan ini menurunkan semangat bertani masyarakat Indonesia.

\section{Kebijakan Harga Eceran Tertinggi (HET)}

Kebijakan penentuan harga gabah atau beras oleh pemerintah sebenarnya merupakan kebijakan yang telah ada sejak lama, meskipun dengan nama program yang berbeda. Dahulu harga gabah/beras petani ditetapkan dengan nama HD (Harga Dasar), kemudian berubah menjadi HPP (Harga Pembelian Pemerintah), menjadi Harga Acuan Penjualan di Konsumen dan Harga Pembelian di Petani, dan saat ini pemerintah menggunakan istilah Harga Eceran Tertinggi (HET). Idealnya kebijakan penetapan 
harga beras mampu melindungi petani agar tidak mengalami kerugian, sekaligus dapat melindungi konsumen agar dapat mengakses beras dengan harga yang terjangkau.

Dalam praktiknya, di masa awal kebijakan penetapan harga beras (HD) condong dimaksudkan untuk melindungi dan mensejahterakan para petani daripada untuk menjaga stabilitas ekonomi. Namun saat ini tujuan tersebut telah bergeser. Merujuk pada bagian pembukaan Instruksi Presiden (Inpres) Nomor 5 Tahun 2015 tentang Kebijakan Pengadaan Gabah/Beras Dan Penyaluran Beras Oleh Pemerintah maka urutan tujuan kebijakan perberasan adalah dalam rangka (1). Stabilisasi ekonomi nasional, (2). Melindungi tingkat pendapatan petani, (3). Stabilisasi harga beras, (4). Pengamanan cadangan beras pemerintah, dan (5). Penyaluran beras untuk keperluan yang ditetapkan oleh pemerintah. Dari data tersebut dapat disimpulkan bahwa stabilitas ekonomi lebih diutamakan daripada melindungi pendapatan petani.

Inpres di atas merupakan aturan dasar dari kebijakan penetapan harga kebutuhan pokok saat ini. Inpres tersebut mengatur harga pembelian gabah dan beras dalam negeri dengan kualitas sedang di pemerintah (Perum Bulog). Beras ditetapkan seharga Rp 7.300,00 jika memenuhi kriteria kadar air maksimum $14 \%$, butir beras yang patah maksimum $20 \%$, kadar menir maksimum 2\%, dan karakter derajat sosoh minimum 95\%. Sementara itu gabah kering panen dihargai Rp 3.700,00 per kilogram dan gabah kering siap giling ditentukan seharga Rp 4.600,00 per kilogram.

Inpres pembelian harga ini tidak begitu memihak petani jika dilihat dari beberapa pertimbangan.

Pertama, dilihat dari inflasi, sejak tahun 2015 sampai saat ini Inpres tersebut tidak direvisi, meskipun inflasi terus terjadi setiap tahun dan UMR juga terus menerus mengalami kenaikan. Bahkan ketika harga BBM dan listrik untuk non-subsidi juga mengalami kenaikan.

Kedua, harga beras di pasaran dalam praktiknya hampir selalu lebih dari Rp 7.300,00 (ketetapan pemerintah). Bahkan BPS memberikan data, rata-rata harga beras di Indonesia pada tahun 2016 adalah Rp 11.511,00 dan harga terendah tidak pernah sampai harga ketetapan pemerintah tersebut (Badan Pusat Statistik, 17 Januari 2018). Meskipun perlu diberi catatan, bahwa meski tidak dicabut Inpres Nomor 5 Tahun 2015, pemerintah telah mengeluarkan Peraturan Presiden (Perpres) Nomor 48 tahun 2016 tentang Penugasan Kepada Perum Bulog Dalam Rangka Ketahanan Pangan Nasional. Perpres tersebut mengatur tentang fleksibelitas harga pembelian pemerintah. Perpres kemudian diterjemahkan oleh menteri perdagangan dalam bentuk peraturan menteri.

Peraturan Menteri Perdagangan (Permendag) terakhir yang mengatur soal beras adalah Permendag Nomor 57 Tahun 2017. Berdasarkan peraturan tersebut pemerintah membuat kebijakan HET berdasarkan wilayah/ zona. Harga beras untuk Pulau Jawa ditetapkan sebesar Rp 9.450,00 untuk beras medium dan Rp 12.800,00 untuk beras premium atau lebih tinggi dari harga menurut Inpres. Dengan adanya ketentuan HET ini maka penjual dan pembeli dilarang menjual beras lebih tinggi dari HET yang telah ditetapkan. Jika ada yang membeli di atas harga HET maka penjual dan pembelinya dapat dipidanakan (Hermawan, 2017: 13). Kebijakan HET merupakan kebijakan yang membuat harga beras murah dan stabil sehingga konsumenmasyarakat terdidik perkotaan tidak protes, 
namun hal ini menimbulkan persepsi petani sebagai tumbal pembangunan.

Salah satu kasus terkait dengan penegakan HET menimpa PT. Indoberas Unggul (IBU). Pada tanggal 20 Juli tahun 2017 Satgas Pangan (Bareskrim) mengrebek dan menyita beras milik PT IBU sebanyak 1.161 ton dan telah melaporkan perusahaan karena membeli gabah kepada petani di atas Harga Pembelian Pemerintah (HPP) dan menjual beras di atas Harga Eceran Tertinggi (HET). Dari kasus ini nampak jelas bahwa pemerintah berusaha menjaga dan mengendalikan agar harga beras tidak naik. Padahal selama ini harga eceran rata-rata beras nasional selalu di atas ketentuan pembelian pemerintah (aturan), bahkan di atas HET. Secara lebih detail perbandingan antara harga peraturan dan harga pasar dapat dilihat dari tabel 1 berikut.

Selain beras ada beberapa jenis produk yang ditetapkan harga acuan penjualan dan harga acuan pembelian. Dalam peraturan menteri perdagangan tahun 2016 terdapat tujuh jenis dan tahun 2007 ada sembilan jenis produk yang ditetapkan harga acuan penjualan dan pembeliannya oleh pemerintah.
Berdasarkan Peraturan Menteri Perdagangan Republik Indonesia Nomor 27/M-DAG/ PER/5/2017 barang tersebut adalah beras, jagung, kedelai, gula, minyak goreng, daging ayam ras, bawang merah, daging sapi, dan telur ayam ras.

Dampak kebijakan penentuan harga eceran tertinggi membuat harga komoditas pertanian (utamanya beras) tidak akan pernah mengalami kejutan harga (yang menyenangkan) bagi petani. Peningkatan pendapatan petani hanya bisa dilakukan dengan cara meningkatkan produktivitas atau mengurangi ongkos produksi dengan cara mekanisasi, yaitu mengganti tenaga manusia dengan alat-alat baru yang tidak banyak membutuhkan tenaga manusia.

Untuk HET komoditas cabai sebenarnya tidak diatur secara spesifik oleh pemerintah. Hanya saja terdapat Peraturan Menteri Perdagangan Nomor 63/M-DAG/ PER/9/2016 tentang Penetapan Harga Acuan Pembelian Di Petani Dan Harga Acuan Penjualan Di Konsumen, yang memuat ketentuan harga cabai merah keriting/besar ketika dibeli dari petani dengan harga

Tabel 1

Perbandingan Harga Beras Menurut Data BPS

Dengan Ketentuan Pemerintah

\begin{tabular}{|c|c|c|c|c|}
\hline No & Tahun & \multicolumn{2}{|c|}{ HET Menurut Peraturan Mentri Perdagangan dan atau Instruksi Presiden } & $\begin{array}{l}\text { Rata-Rata Harga } \\
\text { Beras Nasional } \\
\text { (BPS) }\end{array}$ \\
\hline 1 & 2017 & $\begin{array}{l}\text { Rp7.300,00 (Pembelian di petani) } \\
\text { Rp9.500,00 } \\
\text { (Harga Acuan Penjualan di kon- } \\
\text { sumen); } \\
\text { Permendag Nomor 27/M-DAG/ } \\
\text { PER/5/2017 }\end{array}$ & $\begin{array}{l}\text { Rp9.450,00 } \\
\text { (HET Medium Jawa) } \\
\text { Rp12.800,00 } \\
\text { (HET Premium Jawa); } \\
\text { Permendag Nomor 57/M-DAG/ } \\
\text { PER/8/2017 mulai September } 2017\end{array}$ & Rp11.534,93 \\
\hline 2 & 2016 & \multicolumn{2}{|c|}{$\begin{array}{l}\text { Rp7.300,00 (Pembelian di petani) /Rp9.500,00 (Harga Acuan Penjualan di } \\
\text { konsumen) }\end{array}$} & Rp11.511,34 \\
\hline 3 & 2015 & \multicolumn{2}{|c|}{$\mathrm{Rp} 7.300,00(\mathrm{HPP})$} & Rp10.915,13 \\
\hline 4 & 2014 & \multicolumn{2}{|l|}{ Rp6.600,00 (HPP) } & Rp9.637,88 \\
\hline
\end{tabular}

Sumber : Diolah dengan membandingkan data BPS di https://www.bps.go.id/linkTableDinamis/view/id/963 dengan Permendag dan Inpres terkait harga beras. 
Rp 15.000 dan dapat dijual ke konsumen dengan harga ekonomis Rp 28.500,00. Berdasar ketentuan tersebut maka ketika harga cabai naik akan dilakukan Operasi Pasar untuk menurunkan harga, namun ketika harga cabai di pasar lebih rendah dari harga acuan tersebut pemerintah seharusnya juga membeli cabai petani. Namun dalam pelaksanaannya pemerintah seakan-akan diam saja ketika harga cabai turun dan bergegas impor ketika harga naik. Perlindungan harga cabai menjadi penting karena cabai merupakan komoditas pertanian yang harganya mengalami fluktuasi secara cepat. Salah satu informan dalam penelitian ini bahkan belum pernah sekalipun hasil panennya di beli Bulog. Slamet menuturkan:

“.... walah, seumur hidup belum pernah Bulog membeli hasil tani saya. Kerjaan Bulog-kan menyengsarakan petani, membuat harga (beras dan cabai) yang sudah baik menjadi murah saja. Ketika harga turun drastis mereka diam saja" (Slamet, 19 Januari 2018).

\section{Kebijakan Operasi Pasar (OP)}

Kebijakan Operasi Pasar (beras) merupakan kebijakan yang dilakukan oleh Bulog untuk melepas cadangan beras Bulog dengan harga di bawah harga pasar saat itu. Kebijakan Operasi Pasar didasarkan pada Peraturan Presiden No 20 Tahun 2017 tentang Penugasan Perum Bulog dalam Rangka Ketahanan Pangan Nasional dan Peraturan Menteri Pertanian Nomor 12/Permentan/ PP.320/5/2017 tentang Operasi Pasar Menggunakan Cadangan Beras Pemerintah Dalam Rangka Stabilisasi Harga. Kebijakan seperti ini, yaitu membeli gabah atau beras oleh pemerintah dan menjualnya kembali ketika harga mahal, sebenarnya merupakan kebijakan yang telah muncul sejak tahun 1973.
Kebijakan Operasi Pasar selalu muncul ketika harga komoditas pertanian naik melebihi Harga Eceran Tertinggi (HET) beras kualitas medium yang harganya telah ditetapkan pemerintah, termasuk ketika harga beras naik pada tahun 2018. Secara sederhananya kebijakan Operasi Pasar dilakukan dalam rangka pencegahan atau penanganan lonjakan harga beras. Harga beras dikatakan melonjak ketika peningkatan harga beras di tingkat konsumen terhadap harga normal dan/atau dapat meresahkan masyarakat. Harga Normal adalah harga rata-rata beras kualitas medium di tingkat konsumen sebelum terjadinya lonjakan harga beras. Harga dikatakan melonjak jika harga yang dibayar konsumen paling sedikit mencapai 5\% (lima perseratus) dari harga normal.

Bulog melakukan operasi pasar atas permintaan Menteri Perdagangan setelah mendapat masukan dari kepala daerah (gubernur, bepati/walikota), serta mendapat rekomendasi teknis dari Kementerian Pertanian. Operasi Pasar bisa juga dilakukan atau dihentikan secara langsung atas permintaan menteri pertanian kepada Bulog ketika menghadapi situasi yang mendesak.

Pada tahun 2018, Operasi Pasar beras dilakukan setelah mendapat surat dari Kemendag, tepatnya surat nomor 31/M-DAG/ SD/1/2018 tertanggal 5 Januari 2018. Pada bulan tersebut Bulog DIY melakukan beberapa operasi pasar beras. Harga beras medium yang di pasaran Yogyakarta dijual sampai harga Rp 11.000,00 dalam kegiatan OP dijual dengan harga Rp 9.350,00 per kilogram. Kebijakan ini bertujuan agar harga menjadi normal (turun kembali).

Salah satu OP yang dilakukan di Yogyakarta adalah operasi pasar atas permintaan Bupati Kulon Progo, Hasto 
Wardoyo, ketika harga beras naik. Dari peristiwa tersebut memunculkan pertanyaan, mengapa daerah seperti Kulon Progo yang mempunyai lahan pertanian yang luas (mencapai $10.354 \mathrm{Ha}$ ) dan mempunyai 139.010 orang yang pekerjaannya sebagai petani juga meminta OP. Harusnya Pemkab Kulon Progo sebagai daerah penghasil padi lebih senang dengan kenaikan harga beras (Badan Pusat Statistik Kabupaten Kulon Progo. 2016: 193 dan 213).

Salah satu dasar yang menjadi alasan pemerintah takut dengan kenaikan harga beras adalah dampaknya bagi masyarakat miskin. Penelitian Ikhsan (2001) tentang kemiskinan, menyimpulkan bahwa setiap kenaikan harga beras 10\% akan meningkatkan sekitar $1 \%$ proporsi penduduk miskin di Indonesia. Penelitian tentang efek kenaikan beras ini menjadi argumen penting dalam diskusi tentang kebijakan harga beras (Ikhsan, 2001). Benarkah kenaikan harga beras akan menyusahkan orang miskin untuk mengakses bahan pangan tersebut?

Pemerintah telah mempunyai katup pengaman berupa kebijakan Rastra (Beras Sejahtera). Program ini dulu dikenal dengan nama Program Raskin(Beras untuk Masyarakat Miskin), pernah juga disebut Operasi Pasar Khusus (OPK). Program Rastra merupakan salah satu program perlindungan sosial (social protection) kepada masyarakat miskin dengan memberikan subsidi kepada mereka agar dapat membeli beras dengan harga yang murah dari Bulog. Pada tahun 2017 ketika harga beras di pasaran seharga Rp 9.450,00 per kilogram, masyarakat penerima Rastra dapat membeli beras hanya dengan harga Rp 1.600,00. Dengan demikian masyarakat miskin harusnya tidak akan mengalami kesulitan mengakses beras meskipun harga beras naik secara signifikan.
Jadi kebutuhan beras untuk masyarakat miskin setiap bulannya telah terlindungi oleh kebijakan pemerintah.

Selain Operasi Pasar oleh Bulog pemerintah daerah juga membuat kebijakan-kebijakan sejenis. Hal ini misalnya dilakukan oleh Badan Ketahanan Pangan dan Penyuluhan (BKPP) DIY yang melakukan bazar pangan murah pada tanggal 12 Januari 2018. Kegiatan ini merupakan salah satu upaya BKPP DIY dalam membantu masyarakat untuk mendapatkan beras murah berkualitas di tengah situasi harga beras yang meningkat. Bazar beras BKPP dilakukan di Pasar Beringharjo dan Pasar Kranggan dengan menjual empat ton beras dengan harga $\mathrm{Rp}$ $8.800,00$ per kilogram. Padahal saat itu beras di pasaran harganya masih di atas Rp 10.000,00. Harapannya, dengan harga Rp 8.800,00 tersebut masyarakat dapat memperoleh beras dengan kualitas bagus sehingga akses masyarakat dalam membeli beras dapat dipastikan (Sekretariat BKKP, 15 Januari 2018).

Selain Operasi Pasar beras, OP juga dilakukan ketika harga cabai melambung. Pada tahun 2017, ketika harga cabai merah keriting menanjak sampai Rp 75.000,00 dan di Jakarta sampai Rp 120.000,00 maka Bulog melakukan operasi pasar dengan menjual cabai lebih murah, yaitu Rp 60.000,00. Menurut Bulog mereka membeli cabai tidak dari luar negeri, namun dari daerah-daerah sentra cabai dimana di tingkatan petani cabai dibeli Rp 30.000,00. Ditambah dengan biaya transportasi maka Bulog masih mampu menjual cabai lebih murah dari harga pasar. Selain oleh Bulog, Operasi Pasar cabai tahun 2017 juga dilakukan oleh PT Perusahaan Perdagangan Indonesia (Rai, 10 Januari 2017).

Meskipun Operasi Pasar membuat harga menjadi murah, namun operasi pasar tidak terlalu menjadi persoalan bagi petani jika 
barang yang dijual tidak diambil dari luar negeri (impor). Artinya pemerintah hanya mempercepat proses distribusi dari petani ke konsumen, namun tidak melakukan rekayasa pasar dengan mendatangkannya dari luar negeri. Meskipun demikian melihat kebijakan Operasi Pasar dapat dikatakan semangatnya adalah membuat komoditas pertanian menjadi murah. Hal ini menunjukkan bahwa kebijakan pemerintah tidak terlihat menampakkan keberpihakan kepada para petani.

Ketika harga cabai merah meloncak, pemerintah (Tim Pengendali Inflasi Daerah) DI Yogyakarta berharap harganya segera turun. Keinginan untuk menurunkan harga cabai di Yogyakarta ini menjadi ironi, karena dilakukan ketika banyak petani cabe di Yogyakarta sedang panen. Seharusnya pemerintah senang jika rakyatnya mengalami untung yang banyak. Namun demikian, dalam pelaksanaanya Operasi Pasar cabai lebih sulit dilakukan daripada OP beras karena cabai tidak bisa disimpan terlalu lama (Yanuar, 10 Januari 2017).

Terkait dengan kebijakan Operasi Pasar, sebenarnya petani juga menolak atau tidak setuju, namun mereka masih mentolerir kebijakan ini sehingga petani respons dengan tidak seratus persen menjawab sangat tidak setuju, namun sebagian besar petani hanya masuk dalam skala empat Likert yaitu tidak setuju. Mereka masih memberikan sikap toleran terhadap kebijakan OP karena memang dalam praktiknya masih ada masyarakat yang benar-benar kesulitan untuk mengakses beras. Apalagi di Yogyakarta harga untuk operasi pasar yang dilakukan oleh Bulog harganya sesuai aturan, yaitu Rp 100,00 rupiah di bawah harga pasar Rp 9.350,00 per kilogram. Meskipun demikian sebenarnya kebijakan operasi pasar juga tidak perlu dilakukan. Hal ini karena menimbulkan pertanyaan: untuk siapa operasi pasar ini dilakukan? Jika jawabannya untuk masyarakat miskin, mereka telah ter-cover dalam Program Rastra. Selain itu muncul pertanyaan, apakah pemerintah sudah melakukan pembelian beras dari petani ketika harganya murah? Hampir semua petani mengatakan pemerintah belum membeli beras dan cabai mereka ketika harga jatuh.

\section{Gairah Bertani Dan Harapan Harga Tinggi}

Konsepsi petani yang bergerak secara rasional mempertimbangkan kesejahteraan terlihat dari fenomena petani melon di Kulon Progo. Fenomena petani melon ini bahkan meluas sampai ke Bantul. Di Kulon Progo nampak terlihat ada satu pembagian kerja petani berdasarkan usia dan musim. Ketika musim hujan tiba maka yang menjadi petani adalah orang-orang tua yang usianya telah lebih dari lima puluh tahun. Mereka menanam padi. Namun ketika musim kemarau tiba, orang-orang yang ada di sawah adalah anakanak muda yang bertani melon.

Fenomena ini muncul karena anak-anak muda di Kulon Progo melihat bahwa bertani melon cukup menguntungkan. Pertanian melon ini hanya bisa dilakukan di musim kemarau. Oleh karena itu mereka hanya bertani ketika musim kemarau, sedangkan ketika musim penghujan sawah mereka digarap oleh orang tua yang komoditasnya padi. Melon menjadi menarik karena dalam bertani melon ada pengaharapan (hope) akan kesejahteraan. Jika panennya bagus maka hasilnya pasti akan membuat mereka sejahtera karena selama ini tidak ada kebijakan pemerintah untuk menstabilkan harga melon sehingga jika beruntung mereka akan menikmati kelimpahan uang.

Demikian juga di beberapa tempat ada gairah untuk menanam cabai karena ada 
harapan harga cabai tinggi, meskipun pasti akan diturunkan oleh pemerintah dengan segala cara. Hal ini berbeda dengan beras, ketika harga beras tinggi maka pemerintah dengan segera melakukan operasi pasar dan impor sehingga tidak ada hope akan menikmati kesejahteraan. Pemerintah lebih bisa menyimpan padi (cadangan beras) dalam waktu lama ketimbang cabai.

Jika pemerintah ingin swasembada beras, mengatasi konversi lahan, dan konversi pekerjaaan maka yang dilakukan adalah menumbuhkan hope akan kesejahteraan petani padi. Namun jika hal itu tidak bisa dilakukan maka jangan harap laju konversi lahan pertanian di Indonesia akan dapat diatasi.

\section{SIMPULAN}

Berdasar uraian di atas dapat ditarik simpulan sebagai berikut.

Pertama, Indonesia merupakan negara agraris, meskipun demikian melihat kebijakankebijakan yang dikeluarkan pemerintah ketika harga beras dan cabai naik tidak seratus persen mencerminkan keberpihakan pemerintah terhadap petani sebagai negara agraris. Kebijakan yang diambil pemerintah ketika harga naik antara lain kebijakan impor, Operasi Pasar (OP), dan juga penerapan aturan HET. Kebijakan-kebijikan tersebut menunjukan keinginan dan usaha agar hargaharga turun secara cepat, meskipun dengan cara instant melalui impor. Berdasarkan tiga kebijakan yang dikeluaran, pemerintah "seakan-akan" terlihat kecewa ketika harga beras dan cabai tinggi.

Kedua, petani merespons kebijakankebijakan pemerintah yang diambil ketika harga komoditas pertanian dengan negatif. Semua petani yang dijadikan informan dalam penelitian ini tidak setuju dengan langkah yang diambil pemerintah. Meskipun pemerintah menganggap kebijakan yang diambil tidak akan merugikan petani, namun semua petani mengatakan bahwa mereka sangat tidak setuju dengan kebijakan impor beras. Semua kebijakan yang diambil dianggap bias dari kepentingan petani karena didasarkan semangat penurunan harga.

Ketiga, kebijakan yang diambil pemerintah memberi pengetahuan kepada masyarakat bahwa beberapa harga komoditas pertanian di Indonesia, terutama beras dan cabai, tidak akan dibiarkan tinggi. Hal itu secara langsung akan mempengaruhi pengetahuan dan pemahaman bahwa petani tidak akan pernah mendapatkan kejutan (harapan) kesejahteraan dilihat dari aspek harga. Ini menguatkan bukti statistik yang menunjukan bahwa bekerja di sektor pertanian identik dengan kemiskinan (Badan Pusat Statistik, 2016: 52-53). Jika gairah bertani ini sudah hilang maka usaha pemerintah dengan cara moratorium ijin konversi lahan pertanian tidak akan menyelesaikan masalah, bahkan berakibat pada munculnya lahan-lahan pertanian yang dibiarkan tidak terurus oleh pemiliknya.

Keempat, nasib petani yang pasti tidak akan baik ini menyebabkan gairah bertani menurun. Menurut kacamata teori konflik akan melahirkan perlawanan, baik itu protes demontrasi terhadap ketidakadilan yang mereka terima. Menghadapi kebijakan yang merugikan, ternyata tidak melahirkan gerakan perlawanan petani secara terbuka dalam bentuk protes. Namun demikian situasi tersebut membangkitkan kesadaran dan pengetahuan bahwa bekerja di sektor pertanian tidak akan membuat nasib mereka menjadi baik, akibatnya tidak ada rumah tangga petani yang ingin putra-putrinya bekerja sebagai 
petani. Orang tidak bersedia bekera di sektor pertanian lagi karena bidang ini tidak lagi menjanjikan. Hal tersebut menyebabkan sektor pertanian pangan (beras) tidak terlalu diminati generasi muda. Kondisi ini nampak dari data penurunan jumlah orang yang bekerja di sektor pertanian. Selain itu juga nampak dari angka konversi lahan pertanian yang semakin hari semakin meningkat. Konversi pekerjaan dan lahan ke non-pertanian ini jika dibiarkan dalam jangka panjang akan mempengaruhi ketahanan pangan dan juga ketahan nasional.

Berdasarkan kesimpulan di atas maka penelitian ini merekomendasikan kepada pemerintah untuk melakukan hal-hal sebagai berikut.

Pertama, pemerintah sebaiknya membuat satu proyek percobaan (by design) untuk membiarkan dan sekedar memantau dan melihat apa yang terjadi ketika harga komoditas pertanian melambung. Negara sebaiknya hadir tidak untuk melakukan rekayasa impor agar harga segera turun, namun pemerintah membiarkan mekanisme pasar dan sekedar mengawasi agar tidak ada penimbunan barang. Kenaikan harga komoditas pertanian merupakan harapan petani untuk memperoleh kesejahteraan. Hal ini akan meningkatkan gairah masyarakat untuk bertani dan menyadari posisi Indonesia sebagai negara agraris. Jika pemerintah berkeinginan untuk menjaga stabilitas harga beras maka pemerintah harus lebih serius dalam memberdayakan petani dalam negeri. Hal ini sesuai dengan Undang-Undang Nomor 19 Tahun 2013 yang menyebutkan bahwa petani perlu diberi perlindungan dan pemberdayaan untuk mendukung program negara dalam pemenuhan kebutuhan pangan guna mewujudkan ketahanan pangan secara berkelanjutan.
Kedua, jika pemerintah sudah menentukan harga komoditas pertanian yang layak bagi petani, namun juga dapat diakses oleh masyarakat maka sebaiknya pemerintah menjamin harga tersebut berlaku. Ketika harga komoditas pertanian turun pemerintah perlu berupaya membeli produk tersebut dengan harga yang telah ditentukan sebagaimana pemerintah menentukan harga tertingginya. Dalam kasus turunnya harga cabai, penyerapan produknya dapat dilakukan dengan mengundang pihak ketiga. Pemerintah dapat berperan sebagai penghubung antara petani penghasil cabai dengan pabrik sambal.

Ketiga, laju konversi lahan bukan sekedar kumpulan angka, namun merupakan sebuah indikasi dari satu masalah. Dengan demikian untuk menghentikan laju konversi lahan perlu dicari dan diselesaikan akar persoalannya, yaitu pilihan (pekerjaan) yang menguntungkan bagi petani. Menyelesaikan laju konversi lahan dengan moratorium dan pelarangan serta pemberian sanksi kepada petani untuk alih lahan tidak akan menyelesaikan masalah secara tuntas. Pemerintah perlu membuktikan bahwa mengolah lahan pertanian merupakan pekerjaan yang menguntungkan. Salah satu cara yang dapat dilakukan pemerintah adalah mendorong dan memberdayakan petani untuk menghasilkan produk beras organik ataupun beras kualias premium. Produk ini tidak perlu ditetapkan Harga Eceran Tertingginya (HET) karena ditujukan untuk masuk pasar ekspor dan juga kelompok masyarakat menengah atas.

\section{DAFTAR PUSTAKA}

Asni, Mainil, dkk (editor), Statistik Daerah: Daerah Istimewa Yogyakarta 2016 , Yogyakarta: Badan Pusat Statistik Daerah Istimewa Yogyakarta. 
Pajar Hatma Indra Jaya -- Nasib Petani dan Ketahanan Pangan Wilayah (Studi Tentang Kebijakan Pemerintah dan Respons Masyarakat Desa Mulyodadi, Bantul Ketika Harga Komoditas Pertanian Naik)

Badan Pusat Statistik Kabupaten Kulon Progo, Kabupaten Kulon Progo Dalam Angka 2016, Kulon Progo: PT Pohon Cahaya.

Badan Pusat Statistik Provinsi Daerah Istimewa Yogyakarta, 2013, Laporan Hasil Sensus Pertanian 2013 (Pencacahan Lengkap), Yogyakarta: Badan Pusat Statistik Provinsi Daerah Istimewa Yogyakarta.

Badan Pusat Statistik, 2016, Penghitungan Dan Analisis Kemiskinan Makro Indonesia, Jakarta: Badan Pusat Statistik.

Badan Pusat Statistik, 2018, Laporan Bulanan Data Sosial Ekonomi, Jakarta: Badan Pusat Statistik.

Badan Pusat Statistik, Rata-rata Harga Beras di Tingkat Perdagangan Besar (Grosir) Indonesia 2010-2017, https://www.bps. go.id/linkTableDinamis/view/id/963. 17 Januari 2018.

Budiman, Arif, 2000, Teori Pembangunan Dunia Ketiga, Jakarta: PT Gramedia Pustaka Utama.

Chattopadhyay M., Ghosh B., 1995, Survival Strategy of Farmers: An Ecological Explanation From West Bengal Farms, Journal of Human Ecology, Vol 6, No 3, Hal. 169-175.

Hermawan, Iwan, 2017, Refleksi Kondisi Perberasan Nasional Dari Kasus PT. Indo Beras Unggul, Majalah Info Singkat Ekonomi dan Kebijakan Publik, Vol. IX, No. 15, Hal. 13-16.

Ikhsan, M., 2001, Kemiskinan dan Harga Beras, dalam A. Suryana dan Mardianto (Penyunting), Bunga Rampai Ekonomi Beras, Jakarta: Lembaga Penyelidikan Ekonomi dan Masyarakat, Fakultas Ekonomi, Universitas Indonesia.

Karini, Dyah May, 2013, Dampak Alih Fungsi

Lahan Persawahan Terhadap Produksi
Beras Dalam Rangka Ketahanan Pangan (Studi Kasus Di Kabupaten Tangerang), Jurnal Ketahanan Nasional, Vol. XIX, No. 1, Hal. 12-19.

Kementerian Pertanian RI, 2016, Statistik Pertanian 2016, Jakarta: Pusat Data dan Sistem Informasi Pertanian Kementerian Pertanian Republik Indonesia.

Kementerian Pertanian, 2015, Rencana Strategis Kementerian Pertanian Tahun 2015-2019, Jakarta; Kementerian Pertanian RI.

Kementerian Pertanian, 21 Februari 2017, Kedaulatan Pangan Nasional, $w w w$. pertanian.go.id.

Mulyani, A., Kuncoro, D., Nursyamsi, D., Agus, F., 2016, Analisis Konversi Lahan Sawah: Penggunaan Data Spasial Resolusi Tinggi Memperlihatkan Laju Konversi yang Mengkhawatirkan, Jurnal Tanah dan Iklim, Vol. 40, No. 2 Hal. 121-133.

Narayan, Deepa, 2000, Voices of The Poor: Can Anyone Hear Us?, New York: Oxford University Press.

Popkin, Samuel L, 1976, The Rational Peasan: The Political Economy of Rural Society in Vietnam, Berkeley: University of California Press.

Pramadiba, Istman Musaharun, 12 Januari 2018, Kalla Jamin Impor Beras Tak Akan Cederai Petani, https://bisnis.tempo.co/ read/1049842/kalla-jamin-impor-berastak-akan-cederai-petani.

Putra, Randa Nurianansyah, 2015 , Implementasi Kebijakan Pengendalian Alih Fungsi Lahan Pertanian Di Kota Batu Sebagai Kawasan Agropolitan, Vo. 3, No. 2. Hal. 71-80.

Rahim, Manat, 2010, Dampak Kebijakan Harga dan Impor Beras terhadap Nilai 
Tukar Petani di Pantai Utara Jawa Barat, Trikonomika, Vol. 9, No. 1, Hal. 29-36.

Rai, 10 Januari 2017, 2 BUMN Operasi Pasar Cabai, http://www.bulog.co.id/ berita/37/5988/10/1/2017/2-BumnOperasi-Pasar-Cabai.html.

Scott, James C., 1985, Weapons of The Weak: Everyday Forms of Peasant Resistance, New Haven: Yale University.

Sekretariat BKKP, Bazaar Pangan Murah, BKPP DIY Sediakan 4 Ton Beras, Berita BKKP 15 Januari 2018, http://bkpp. jogjaprov.go.id/content/read/1033/ Bazaar-Pangan-Murah\%2C-BKPP-DIYSediakan-4-Ton-Beras.

Siringo, H. B., Daulay, M., 2014, Analisis Keterkaitan Produktivitas Pertanian Dan Impor Beras Di Indonesia, Jurnal Ekonomi dan Keuangan, Vo. 2, No. 8, Hal. 488-499.

Soekarno, 1952, Soal Hidup atau Mati, dalam A. Fariyanti, A. Rifin, S. Jahroh, dan B. Krisnamurthi, 2014, Pangan Rakyat: Soal Hidup atau Mati 60 Tahun Kemudian, Bogor: Departemen Agribisnis FEM IPB dan PERHEPI.

Solivetti, Luigi M., 2005, W.W. Rostow and His Contribution to Development Studies: A Note, Journal of Development Studies, Vol. 41, No. 4, Hal. 719-724.

Suryana, A., Rachman, B., dan Hartono, M. D., 2014, Dinamika Kebijakan Harga Gabah Dan Beras Dalam Mendukung Ketahanan Pangan Nasional, Pengembangan Inovasi Pertanian, Vol. 7, No. 4, Hal. 155-168.

Tribun Yogyakarta, 15 September 2017, Petani Di Bantul Ini Bagi-Bagikan Cabai Miliknya Secara Gratis Ternyata Begini Kisah Di Baliknya, http://jogja. tribunnews.com/2017/09/15/petani-di- bantul-ini-bagi-bagikan-cabai-miliknyasecara-gratis-ternyata-begini-kisah-dibaliknya.

Wibowo, Catur Setyo, 2015, Dampak Pengalihan Fungsi Lahan Sawah Pada Produksi Padi Sampai Tahun 2018 Dan Implikasinya Terhadap Ketahanan Pangan Wilayah (Studi Di Kecamatan Jaten Kabupaten Karanganyar Propinsi Jawa Tengah), Jurnal Ketahanan Nasional, Vol. 21, No. 2, Hal. 107-117.

Yanuar, Jurus Meredam 'Pedasnya' Harga Cabai di Yogyakarta, 10 Januari 2017, http:// regional.liputan6.com/read/2822421/ jurus-meredam-pedasnya-harga-cabaidi-yogyakarta.

\section{Peraturan Perundangan}

Undang-Undang Nomor 18 Tahun 2012 tentang Pangan

Peraturan Presiden Republik Indonesia Nomor 48 Tahun 2016 tentang Penugasan Kepada Perum Bulog Dalam Rangka Ketahanan Pangan Nasional.

Peraturan Presiden Republik Indonesia Nomor 20 Tahun 2017 tentang Penugasan Perum Bulog dalam Rangka Ketahanan Pangan Nasional.

Instruksi Presiden Republik Indonesia Nomor 3 Tahun 2012 tentang Kebijakan Pengadaan Gabah/Beras Dan Penyaluran Beras Oleh Pemerintah.

Peraturan Menteri Perdagangan Republik Indonesia Nomor 63/M-DAG/PER/9/2016 tentang Penetapan Harga Acuan Pembelian Di Petani dan Harga Acuan Penjualan Di Konsumen.

Peraturan Menteri Perdagangan Republik Indonesia Nomor 27/M-DAG/PER/5/2017 tentang Penetapan Harga Acuan Pembelian 
Pajar Hatma Indra Jaya -- Nasib Petani dan Ketahanan Pangan Wilayah (Studi Tentang Kebijakan Pemerintah dan Respons Masyarakat Desa Mulyodadi, Bantul Ketika Harga Komoditas Pertanian Naik)

Di Petani Dan Harga Acuan Penjualan Di Konsumen.

Peraturan Menteri Perdagangan Republik Indonesia Nomor 57 Tahun 2017.

Peraturan Menteri Perdagangan Republik Indonesia Nomor 1 Tahun 2018 tentang Ketentuan Ekspor dan Impor Beras.

Peraturan Menteri Pertanian Republik Indonesia Nomor 12/PERMENTAN/
PP.320/5/2017 tentang Operasi Pasar Menggunakan Cadangan Beras Pemerintah Dalam Rangka Stabilisasi Harga.

\section{Wawancara}

Jono, petani di Desa Mulyodadi, tanggal 13 Januari 2018.

Slamet, petani di Desa Mulyodadi, tanggal 19 Januari 2018. 